\title{
Citizen participation in crime prevention: a study in Kuching, Sarawak, Malaysia
}

\author{
Pang Heng Lau and Kamsiah Ali
}

Pang Heng Lau and Kamsiah Ali are both based at the Department of Social Sciences and Humanities, Universiti Malaysia Sarawak, Kota Samarahan, Malaysia.
Received 30 January 2019

Revised 27 April 2019 24 May 2019

Accepted 28 May 2019

\begin{abstract}
Purpose - The purpose of this paper is to discuss citizen participation in crime prevention in Kuching, Malaysia. This is a study of how citizen participated in crime prevention has helped in crime reduction in Kuching. Roles of citizen in crime prevention with the police have been included in this study. Result showed that citizen and police joint crime prevention has succeeded in crime reduction in Kuching.

Design/methodology/approach - Three methods of data collection were used in this research study: first, face-to-face interviews of 500 head of households in Kuching. They are selected using systematic sampling among the 159,000 households in Kuching. Second, in-depth interviews of 36 respondents involving community leaders and crime watch groups; and third, secondary crime statistics from the Royal Malaysia Police. It is based on actual crime reported to the police.

Findings - Police and citizen involvement in crime prevention are effective in reducing crime. Citizen participation in crime prevention was 80.6 per cent. The higher the frequency police and citizen involvement in crime prevention patrols, the lesser the level of crime. With increased joint patrol by police and citizen in the neighbourhood, the level of crime will be lower, and safety will improve, and this is particular valid in the case of the nine geographical areas covered under Kuching police district.
\end{abstract}

Research limitations/implications - This study focused on citizen participation in crime prevention in Kuching police district only.

Practical implications - Police and citizen participation in crime prevention play a key role in crime reduction. This study argued that police and citizen frequent patrol will improve safety in the community. Training plays a key role for citizen to participate in crime prevention. Joint crime prevention patrol calls for a new breed of police officers who can work with the citizens. In return, the citizens trust the police to lead them in crime prevention.

Social implications - With citizen participation in crime prevention, the community will be safer, peaceful resulting in less crime. Citizens acted as an eye and ear to the police. As and when a citizen see a suspicious person in the neighbourhood, he informs the police. When the police arrives, the suspicious person who may have a criminal intent will either be arrested by the police or escaped before the police arrived.

Originality/value - This paper provides an insight into crime prevention exercise involving the citizens. The same concept can be implemented throughout Malaysia. Police needs to involve citizens always in crime prevention. Police and the community are one big family.

Keywords Crime prevention, Policing, Community policing, Citizen participation, Crime watch

Paper type Research paper

\section{Introduction}

Preventing and detecting crimes and preserving public peace in Malaysia have been the central mandate of the police since 1807 (Khan, 2015). The Royal Malaysia Police (RMP) has invited citizens to participate in crime prevention since 1967 under the "Salleh" system (Sulaiman et al., 2012). The "Salleh" system based on the Japanese "Koban" system of policing had, in 1967, evolved to the Malaysian Volunteer Corps Department (RELA), Neighbourhood Watch (Kawasan Ronda Tetangga (KRT)), Voluntary Patrol Scheme (SRS), Rakan Cop and to the present day "community policing" (Royal Malaysia Police, 2019).

The reason for having citizen participation in crime prevention is due to increasing concerns over rising crime rates in the country. Crime occurs in the community, thus by involving citizens in 